\title{
Economic efficiency of high-rise construction in the Moscow program of renovation of housing stock
}

\author{
Andrey Misailovov ${ }^{1, *}$ \\ ${ }^{1}$ Moscow State University of Civil Engineering, Yaroslavskoye shosse 26, Moscow, 129337, Russia
}

\begin{abstract}
The article considers a new initiative of the regional authorities of updating the housing stock designated as the renovation of housing. Its main aspects are analyzed, including the nature of program, economic efficiency of its implementation due to high-rise construction and the regulatory and legislative framework, the procedure for implementing the program, and the time frame for its implementation. The role of the program for regions in which high depreciation of the housing stock is combined with a limited number of sites for a new housing construction is disclosed. The high-rise construction in the renovation program is presented as a variant of a successful solution not only of the tasks of renovating the housing stock, but also of filling the regional budget. The social and economic orientation of the high-rise construction and the involvement of residents in the process of making town-planning decisions in the field of high-rise construction at all stages of implementing the program are shown.
\end{abstract}

\section{Introduction}

Economic efficiency of investments in high-rise construction is a guarantee of successful solution of social tasks and maintaining the stability of the region. In the Moscow region the development of the construction industry has not changed the number of facilities, budget financing, contracts price. Invested in the high-rise construction Finance provide significant economic impact and are considered to be an important anticrisis measure. The correct policy of investment in high-rise housing construction helps the city administration to increase annually the volume of budgetary funding and to implement more large-scale entrepreneurial projects.

The high level of business development is supported by investments into creation projects of qualitatively new housing. It basis on the progressive innovative technical and technology solutions, designs, materials and the equipment, normative, technical, scientific, methodical documentation. These projects have successfully passed the analysis of economic efficiency (including budget expenses calculated with the use of the base prices of material resources, labor input of works, costs of use of cars and mechanisms, overhead costs, wholesale prices for production) in comparison with applied earlier analogs. Positive results of using new projects in high-rise housing construction have allowed to finish complex technical and material work and since the end of 2014 to notify all house-building

*Corresponding author: $\underline{\text { stanu@yandex.ru }}$ 
plants of the Moscow region about transition of construction to the houses of new series. It is important to note that Moscow from the city budget supported those organizations which according to the new project modernized their production in order to recieve in 2016-2017 full transition to new housing series [1].

The model of development of business in high-rise housing construction considered complex relationship between the state and private business which cornerstone the aspiration to get profit from rivalry and interaction.

One of the features of modern construction business is in combining efforts of the companies for production and receiving profit thanks to more effective mechanisms of sales. As show examples of business cooperation, the modern construction market isn't any more the place only of competitive fight. In fact it is possible to speak about formation of new type of the housing construction market. The awareness of need of strategic alliance for acquisition and support of competitive advantage and a possibility of simultaneous competition and cooperation with other construction companies is one of its characteristics [2]. Appeared model of interaction between the state and private business allowed to develop the program of renovation of the Moscow housing stock directed to solve urgent social tasks and which is, in fact, the favorable entrepreneurial project.

\section{Materials and Methods}

The Moscow city law dealing with the program of demolition five-floor houses adopted in 1998 nowadays is in a conflict with a large amount of the federal norms appeared the last years. The lack of necessary precepts in the law does not allow execution of the program of renovation in a reasonable time. In particular, existing rules don't provide demolition of shabby housing (like five-floor houses) and concern only emergency housing. The existing standards of the town-planning, land and budgetary legislation are not so suitable for renovation of the existing urban development. As a result demolition of each residential district of five-storey buildings drags on for years, and the whole program - for decades. It is considered that this law has completely sputtered out, and the solution of problems of the accelerated renovation becomes possible with adoption of the special federal law. It will give the start to large-scale implementation of the program of renovation of housing stock. The program of renovation is designed to update housing stock of Moscow without waiting five-storey buildings finally turn into the hazardous dwelling. Thanks to the program of renovation the Muscovites living in shabby five-floor houses will be provided with modern well-planned apartments.

The program of renovation of housing stock represents demolition of shabby houses (often five-floor) and construction of modern residential multi-storey quarters. The program is socially oriented and as much as possible meet the interests of Muscovites. The inhabitants of the demolished five-storey buildings are free of charge and will receive equivalent well-planned apartments in new high-rise houses in the area of residence. The broad information support of the program is provided. Reference information can be obtained on the official Internet portal of the mayor and the Government of Moscow (mos.ru), in information centers of justices of areas and prefectures of administrative districts, in the offices of the state services "My Documents". The problem of information maintenance includes creation such conditions which allow inhabitants of shabby houses make a conscious choice about inclusion or non-inclusion their houses in the program of renovation. So, the offices of justices of areas and prefectures of administrative districts have to provide the broadest informing of citizens about the program [3].

The need of carrying out renovations is connected with that fact that five-floor houses of the first period of industrial housing construction in Moscow (from 1957 to 1975) have saved up the sufficient level of wear. Besides, in the city there are five-floor houses built 
earlier and there are houses two-four floors high, technical characteristics of which are similar to five-floor houses. The majority of these houses according to calculations should operate within 25-50 years. Since 1988, the Government of Moscow worked with the program of resettlement and demolition of five-floor houses to help over 160 thousand Moscow families to receive new apartments. In the 2000th years the method of so called "wave resettlement" was practiced. Inhabitants of the demolished houses moved to new houses. Only after that demolition of old and construction in the freed territory of new residential high-rise buildings was carried out. At the same time, in Moscow there are about eight thousands five-floor houses of the first period of industrial housing construction carried to the so-called not taken down series, and as have shown technical inspections considerable part of which is also in an unsatisfactory state, and conditions of accommodation of inhabitants don't meet modern safety requirements and comfort.

Since February 2017, active work was carried out to prepare the necessary laws and regulations. The Government of Moscow has set a number of the tasks which solution is necessary to start implementation of the program, among them:

- to adopt the federal law on renovation and city norms and rules providing its execution;

- to find out opinion of inhabitants on inclusion of their house in the program of renovation and then on the basis of the received decision define the lists of the five-floor houses to demolish;

- to pick up free sites for construction of starting (first) houses, including residential high-rise buildings;

- to allocate budgetary funds for the start of the program;

- to define mechanisms of investments because of the lack of budgetary funds for implementation of the program of renovation.

The main terms of granting new apartments according to the Moscow standard and to the program of renovation are the following:

- granting the equivalent apartment in the new house with identical number of rooms, living space not less then in the apartment in the five-floor house which is subjected to demolition, more spacious rooms of general use (kitchen, a hall, a corridor, a bathroom, a toilet);

- granting the new apartment in the area of residence in any district in the city, except central district, Zelenograd, Troitskiy district and Novomoskovskiy district in which housing will be provided within the administrative district;

- granting new apartments in property, and also (at the request of employers of housing in the demolished houses) under the contract of social hiring;

- granting new apartments to people in the waiting list with simultaneous improvement of living conditions and space;

- new apartments are provided with comfort class finishing;

- in quarters of renovation high-quality improvement is carried out.

It is emphasized that despite the increase in the area of new apartments (first of all, at the expense of more spacious rooms of general use - kitchens, halls, corridors, bathtubs, toilets) it will cost nothing to people.

For resettlement of inhabitants of five-floor houses, new high-rise houses will be built of modern materials (a monolith or the panel of new generation) and using modern projects - with elevators and spacious entrances. Ceilings in new apartments will be higher, and sound insulation will be much better, than in panel five-storey buildings. Also doubleglazed windows are envisaged in apartments. In apartments, as a rule, will become possible carrying out re-planning. Entrances and lift halls will be at one level therefore the disabled persons or parents with a baby carriage will be able to come freely into the house and to rise at any floor. 
Due to the announced initiatives, the appearance of Moscow will be improved by bright and non-standard facades of the new high-rise houses built on the places of the demolished five-storey buildings. The predicted term of their service will be at least 100 years, and in case of appropriate service and repairing much longer. Along with the fact that it is guaranteed to inhabitants of five-floor houses that the new apartment will be in the same area (except for central district, Zelenograd, Troitskiy district and Novomoskovskiy district), inhabitants also have an opportunity to chose apartments provided according to the program of renovation in the other desirable free area.

Since the beginning of 2017 the Moscow City Architecture Committee and prefectures of administrative districts conduct active work on selection of launch pads in all areas where it is planned to begin the program of renovation. The actual list will be approved after adoption of the program. Renovation supposes demolition of quarters of five-floor houses and construction new high-rise buildings, so called "point" demolition is possible as an exception for separate five-storey houses. For an additional fee residents of the moved houses have an opportunity to get the apartment with a large number of rooms and the bigger space, than apartment which is free of charge according to the program of renovation. The cost of "square meter" will be market in case of acquisition the bigger apartment, however it is important to note that at the same time various flexible systems of discounts and payments are provided.

The program is especially favorable to a large number of the Muscovites standing in a queue on improvement of living conditions. First, expectation terms in a turn will be considerably reduced, and Muscovites will need only one moving. Secondly, within the program of renovation they will get new apartments with simultaneous improvement of living conditions on norms of granting living space depending on family composition. Great social value belongs to mechanisms of resettlement of families, especially in not privatized apartments where divorced spouses and the grown-up children live. Muscovites can refuse to get equivalent apartment in the new house and choose one of resettlement options. Their resettlement in the area of residence will become possible on condition of additional payment, and in case of unwillingness to incur material inputs, such Muscovites will be able to be settled to the area with lower cost of apartments. It should be noted, an opportunity to choose the way of resettlement combines both options. Resettlement of owners of communal flats will be carried out to different apartments according to the law of the city of Moscow of May 31, 2006 No. 21 "About ensuring the housing rights of citizens at resettlement and release of premises (houses) in the city of Moscow" which forbids granting rooms to citizens in communal flats.

According to the program of renovation the homeowners in the five-floor house registered in other apartment will be able to receive the equivalent apartment, or receive monetary compensation in a natural form instead of the apartment. At the same time the amount of compensation will be calculated, proceeding from the market value of the old apartment. Considering that the cost of the new apartment will be 20-30 percent higher then old, supposed that receiving compensation is economically unprofitable for inhabitants of five-storey buildings. Besides, the rules of receiving compensation will have to guarantee respect for the housing rights of socially vulnerable categories of citizens - first of all, minor children and incapacitated persons [4].

Positive social factor of implementation of the program is planning of the work with preferential categories of citizens - lonely pensioners and families of pensioners who will be given help not only in moving, but also arrangement in the new apartment. Resettlement of inhabitants to new apartments will be carried out regardless of existence their debts on payment of housing and communal services in old apartments, as moving to the new apartment won't exempt the debtor from a duty to pay the debt. No special measures will be taken to debtors in connection with implementation of the program of renovation, will be 
provided to them just the same apartments, as well as to inhabitants who have no debt on housing and communal services.

\section{Results}

Options of work with apartments in five-floor houses which are in pledge at bank are worked out in the program. The terms "equivalent apartment" and "equal price apartment" are specified. The equivalent apartment is understood as the new apartment which according to the consumer characteristics (the apartment's area, number of rooms, district) is same (or the best) in comparison with old. The equal price apartment is understood as the new apartment which market value is equal to the market value of the old apartment. It is considered that receiving the equivalent apartment is much more favorable to inhabitants, than receiving equal in price apartment because the cost of square meter in new houses will be much higher, than in five-floor houses. In quarters of renovation on the place of the demolished houses the modern standards of improvement (including creation of local parks, bicycle tracks, public sports, children's and leisure infrastructure) will be applied, at the same time the area of green plantings will be kept or increased. It is additionally noted that projects of new high-rise quarters will be developed with participation of the best domestic and world urban architects, experts in the field of transport, design and urban environment. Warranties and the accounting of interests of owners of non-residential premises in the demolished houses are important for preservation of infrastructure in areas of building. At own choice people will be able to receive either compensation of market value of the withdrawn real estate, or equivalent non-residential premises to continue business activity.

It is defined that for inclusion the house in the program of renovation, it has to satisfy two main conditions:

- the five-floor house has to be in unsatisfactory technical condition;

- most of inhabitants (owners, employers of apartments under the contract of social hiring, constantly registered citizens) have to support inclusion the house in the program.

Houses which have been built till 1957, but with the same characteristics can be involved in the program of renovation with the consent of inhabitants. Comfortable fivefloor houses which are in satisfactory condition won't be involved in the program of renovation, and problems of such houses will be solved within the program of capital repairs. On the basis of the analysis of the received results of polls, the preliminary list of houses involved in the program of renovation has been formed. Development of the program of renovation could not be possible without serious analytical researches among which:

- the carried-out analysis of more than 250 thousand appeals of inhabitants of the fivefloor houses sent to Moscow authorities in recent years;

- initiatives in March-April, 2017 of prefectures of administrative districts about carrying out consultations with deputies of local government and seniors of houses about inclusion five-storey buildings in the program of renovation;

- the conducted telephone survey (in the second half of April, 2017) of inhabitants of five-floor houses to clarify their preliminary opinion of desirability/undesirability in participation in the program of renovation;

- analyzing technical information of condition of houses.

The final list of the houses involved in the program of renovation will be defined according to the results of vote of inhabitants of five-storey buildings taken from May 15 to July 1, 2017. Inhabitants of the five-storey buildings included in the preliminary list will receive notices (via message boards near their entrances, e-mail) with the offer to take part in vote. Some inhabitants will be notified by SMS mailing. The categories of inhabitants of the five-floor houses included in the preliminary list will be the following: owners of 
apartments (including all owners of shares), the citizens having contracts of social hiring and the citizens having constant registration. From each apartment several people will be able to vote, at the same time each inhabitant has only one voice. The tenants of apartments and those people who have temporary registration with successors and relatives of inhabitants of five-storey buildings have no right to take part in vote.

Discussion of the program has revealed a wide range of supporters of renovation of whose houses which were not included into the preliminary list. Therefore the inhabitants of the five-floor houses which aren't included in the preliminary list will be able to fill up the application for participation in the program of renovation in the electronic system "Active Citizen" or in the multipurpose center "My Documents". If the house gets a significant amount of applications, then additional vote with participation of all inhabitants will be taken. In case of positive result of vote the house will be included in the program of renovation. At the same time it is noted that during discussion an influence on decisionmaking is allowed in any honest ways, without violating the standard rules of conduct. In case of existence of the town-planning opportunity, first of all will be resettled those houses which inhabitants most actively participate in vote and have collected the maximum poll for participation in the program of renovation [5].

Other houses can also be included in the program of renovation, for example, panel nine-floor buildings, but at observance of a number of conditions. First, according to technical and constructive characteristics nine-floor or any other houses has to be same as houses of the first period of industrial housing construction. Secondly, technical condition of the house has to be unsatisfactory. Thirdly, the house has to be in borders of quarter of renovation (that is near five-floor houses). Besides, inhabitants have to suggest including the house in the program of renovation and by vote to collect a majority of votes «for renovation». If the house meets the first three requirements, then its inhabitants can fill up the application for participation in the program of renovation in the "My Documents" center or using the electronic system "Active Citizen". It is expected that renovation will be carried out at the same time across all territory of the city as in perspective areas, and in less prestigious areas [6]. The sequence of resettlement and demolition is put into dependency on readiness of inhabitants to participate in the program, existence of free areas for building and from some other conditions.

\section{Discussions}

Projects of the organization of high-rise construction will be made to cause as little inconveniences to inhabitants of nearby houses as possible. In this regard terms of construction will be reduced. Federal and city laws on quality control of construction works and respect for silence on the days off and at night fully extend to the program of renovation. Projects of the organization of construction of new high-rise houses will be made to exclude any damage to nearby building, so neither strengthening of the bases, nor any other preventive actions for the houses adjoining on quarters under construction will be required.

\section{Conclusion}

Thus, the program of renovation of housing stock is an entrepreneurial initiative of the Moscow authorities allowing to solve social problems: to reach comfort class in living conditions for people on the waiting list and inhabitants of not prestigious five-storey buildings on suburbs of the city, to apply resettlement of communal flats, to start improvement in quarters of accommodation, to get an "alignment" of an external 
architectural form of all districts in relation to the center. Also some economic problems can be solved: financing of the project from non-budgetary funds, gaining on an economic efficiency due to increase in number of storeys, guaranteeing payments of owners to the city budget for a prolonged period of time.

\section{References}

1. P.G. Grabovy, A.K. Orlov. Procedia Engineering, 153, 195-202 (2016)

2. V.S. Kankhva. Immovable property: economy, management, 3, 17-19 (2009)

3. S.V. Domnina, E.V. Savoskina, N.V. Shekhova. Procedia Engineering, 153, 741-746 (2016)

4. A. Larionov, E. Nezhnikova. International Journal of Applied Engineering Research, 6 (11), 4433-4439, (2016)

5. A. Larionov, E. Nezhnikova. ARPN Journal of Engineering and Applied Sciences, 3 (11), 2023-2029, (2016) 